\title{
A TRADUÇÃO DE LITERATURA INFANTIL PARA LIBRAS: A EXPRESSIVIDADE DO CORPO NA PRODUÇÃO DE SENTIDOS
}

\author{
THE INTERPRETATION OF CHILDREN'S LITERATURE INTO BRAZILIAN SIGN \\ LANGUAGE (LIBRAS): BODY EXPRESSIVENESS IN THE PRODUCTION OF \\ MEANING
}

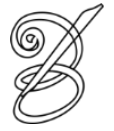

Arlene Batista da SILVA*

Universidade Federal do Espírito Santo, Brasil

Marcilene da Penha Gonçalves BRAVIM**

Universidade Federal do Espírito Santo, Brasil

\begin{abstract}
Resumo: Este artigo ${ }^{1}$ objetiva analisar a tradução de Libras no contexto contemporâneo, tomando como foco a expressividade do corpo como elemento produtor de sentidos. Ancorados nos estudos de Hall (1997), Karnopp (2013), Morgado (2011) e Chartier (1990), entre outros, pretende-se descrever e interpretar a performance poética dada a ver na obra literária "As aventuras de Pinóquio", produzida pela Editora Arara Azul. Na análise, almeja-se identificar os modos como o tradutor utiliza as expressões faciais e corporais, os classificadores, o olhar, a movimentação dos ombros e a incorporação de personagens com vistas a verificar se ocorre uma materialização da literatura do/no corpo do sinalizador por meio dos recursos expressivos da Libras. No estudo, foram utilizados os princípios metodológicos da pesquisa documental. A partir das análises foi possível perceber que o tradutor lançou mão do uso abundante dos classificadores, das expressões faciais/corporais, dos movimentos e dos elementos imagéticos, todos em consonância uns com os outros para que o leitor (receptor) derive claramente a trama. Com esses recursos, cria possibilidades para que o leitor possa se emocionar e envolver-se na história ao ver/ler a narrativa performatizada no corpo do sinalizador.
\end{abstract}

Palavras-chave: Literatura Infantil. Libras. Expressividade. Sentido.

Abstract: This research subproject is integrated to the main project $n^{\circ}$ 6850/2016 - Translation and Interpretation of Brazilian Sign Language (Libras) in the contemporary context: challenges and perspectives - and to the Study and Research Group in Sign Language: Interpretation and Translation (LISIT), developed by professor Dr. Arlene Batista da Silva from the Department of Languages and Letters (DLL / CCHN) of Ufes (Universidade Federal do Espírito Santo). It is a desk research that focuses on an analysis of the translation of children's literature into Brazilian Sign Language (Libras), focusing on the expressiveness of the body as a meaning-producing element. Anchored in the studies of Hall (1997), Karnopp (2013), Morgado (2011) and Chartier (1990), among others, we intend to describe and interpret the poetic performance present in the literary work "The Adventures of Pinocchio", produced by Editora Arara Azul. In the analysis, we aim to identify the ways in which the translator uses facial and body expressions, classifiers, the gaze, the movement of the shoulders and the embodiment of characters in order to verify whether there is a materialization of the literature of / in the body of the signer through the expressive resources of Brazilian Sign Language (Libras). From the analysis, it was possible to realize that the translator used classifiers, facial / body expressions, movements and imagetic elements abundantly, all in consonance with each other so that the reader (receiver) clearly derives the plot. With these resources, possibilities for the reader to be touched and involved in the story by seeing / reading the performative narrative in the body of the signer are created.

Keywords: Children's literature. Brazilian Sign Language, Expressiveness. Meaning. 
RECEBIDO EM: 20 de fevereiro de 2019

ACEITO EM: 24 de maio de 2019

PUBLICADO EM: julho 2019

\section{As crianças surdas e a literatura em língua de sinais}

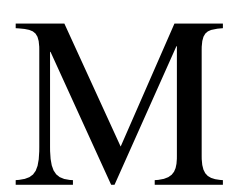

orgado (2011) discute a importância da literatura tanto para crianças ouvintes como para crianças surdas, pois a leitura do texto literário favorece o desenvolvimento da imaginação de modo que a literatura, de forma geral, possibilita a transmissão de cultura, conhecimento e visão de mundo, viabilizando, ainda, o desenvolvimento da memória, da concentração e da criatividade da criança.

No livro "Literatura em língua gestual"2 (2011), a autora portuguesa evidencia que a literatura voltada aos sujeitos surdos não se preocupa, a priori, com a forma textual ou mesmo com a estética das palavras. Na verdade, esse tipo de literatura se ocupa principalmente com os aspectos gestuais e expressivos. Para a autora, a expressão "literatura" pode ser entendida como correspondente a "enunciado gestual artístico", o qual se preocupa com a estética dos gestos. Nessa lógica, de acordo com Morgado (2011, p. 151), a substituição do termo "texto" por "enunciado gestual" e "palavras" por "gestos" seria mais adequado.

Morgado ressalta um fato que traz implicações diretas à compreensão dos textos literários, qual seja: o aprendizado da língua materna. Enquanto a criança ouvinte vai para a escola fluente em sua língua materna, a maior parte das crianças surdas aprendem Libras tardiamente, a partir dos sete anos de idade ou mais. Nesse contexto, quando os livros de literatura são escritos em segunda língua, dificultam o entendimento das crianças surdas que ainda estão em processo de apropriação da língua de sinais (língua materna). Quando, porém, a literatura é produzida por professores surdos que sejam fluentes em língua de sinais, é uma fonte de riqueza para as crianças, por meio da qual ela é estimulada a pensar, a agir, torna-se autônoma e melhora autoestima, pois começa a ter acesso ao mundo e aos conhecimentos.

De acordo com Morgado (2011), quando o texto literário é sinalizado por professores surdos, há um impacto maior na vida da criança surda, pois eles participam de uma vivência diferente dos ouvintes, ou seja, constroem o pensamento a partir da experiência visual tal como as crianças. Assim, quando é oferecida uma literatura na língua própria da criança surda, possibilita-se que ela expanda seus horizontes em todos os contextos, principalmente no linguístico, no cognitivo e, assim, no cultural. 
A autora, corroborando com os postulados de Bahan (apud MORGADO, 2011), entende que a literatura das línguas de sinais, quando é bem elaborada, origina histórias, contos, narrativas, fábulas, anedotas, poesia, jogos, piadas e caricaturas.

\section{Diálogos sobre a cultura e seus artefatos}

Esta pesquisa estabelece uma interlocução com os estudos teóricos de Hall (1997) e Roger Chartier (1990) acerca da cultura e sua materialização nas práticas sociais e nos artefatos produzidos pelos sujeitos em suas realidades particulares.

De acordo com Chartier (1990), a matriz teórica chamada Nova História Cultural investiga as expressões culturais de pessoas comuns no cotidiano, abarcando diversos grupos sociais sem prescindir das questões políticas e econômicas que os envolvem.

Chartier apresenta noções conceituais considerando os diferentes modos, nos diversos lugares e momentos, da construção de uma determinada realidade social. Com isso, de acordo com o autor, viabiliza-se a compreensão da maneira pela qual essa realidade é construída e pensada. $\mathrm{O}$ autor afirma que as representações do mundo social, embora aspirem à universalidade de um diagnóstico fundado na razão, são sempre determinadas pelos interesses dos grupos que as forjam. Desse modo, para cada situação é necessário relacionar os discursos proferidos com a posição de quem os utiliza.

Ainda de acordo com Chartier, as práticas humanas dão sentido ao mundo e são resultado das representações que os sujeitos constroem da realidade, seus valores, ideias e conceitos. Os diferentes modos como as pessoas se apropriam, isto é, interpretam e fazem uso das práticas, estão relacionados às determinações fundamentais que os constituem como sujeitos. Assim, a noção de apropriação, segundo Chartier, está na diferença do uso partilhado, tal como identifica, a partir de Pierre Bourdieu:

[...] o gosto, a propensão e aptidão para apropriação (material e/ou simbólica) de uma determinada classe de objetos ou práticas classificados ou classificadores é a forma geradora que se encontra no princípio de estilo de vida, conjunto unitário de preferência distintivas que exprimem, na lógica específica de cada um dos subespaços, simbólicos, a mesma intenção expressiva. (BOURDIEU apud CHARTIER, 1990, p. 193).

A partir dos conceitos da Chartier, podemos entender que o DVD "As aventuras de Pinóquio" é um objeto cultural que se constitui a partir de práticas, representações e apropriações que retratam dois modos distintos de produção de sentido: por meio da linguagem 
escrita (português) e da visual produzida no corpo do sinalizador (Libras), sendo essa última a que será abordada nesta pesquisa.

Considerando os apontamentos de Chartier (1990), percebe-se o fato de que, quando se fala de literatura surda, esta não é apenas uma narrativa em Libras, mas, na verdade, uma experiência sociocultural, com práticas culturais diferentes, que têm uma história cultural com representações diversas que mostram acontecimentos e que produzem sentido.

Na condução deste estudo, também dialogaremos com a obra do sociólogo Stuart Hall, que trata da centralidade da cultura no contemporâneo. De acordo com Hall (1997), a identidade do ser é constituída por meio da cultura, que faz parte da vida do indivíduo. Para o autor, a cultura funciona como um elo entre o sujeito e a sociedade, faz parte da vida cotidiana da pessoa. Dessa forma, destaca-se sua inseparabilidade do meio social. Com isso, por estar diretamente inserida na sociedade, atravessa gerações que, por sua vez, incorporam as práticas.

O autor, nessa direção, discute sobre o local da cultura, sobre sua centralidade na contemporaneidade e sobre o modo pelo qual ela ocorre dentro da sociedade. Além disso, evidencia de que forma é percebida e vivida, apresentando centralidade substantiva e 204 epistemológica. Com isso, discorre também sobre aspectos referentes à regulação cultural e tomada de regulação, à transformação cultural local cotidiana, ao governo da cultura e à virada cultural. Hall define centralidade substantiva e epistemológica da seguinte forma;

Centralidade substantiva refere-se ao [...] lugar da cultura em sua condição empírica real e na organização das atividades, instituições, e nas relações culturais envolvidas na sociedade, em qualquer momento histórico particular e a centralidade epistemológica refere-se à posição da cultura em relação às questões de conhecimento e conceitualização, em como a "cultura" é usada para transformar nossa compreensão, explicação e modelos teóricos do mundo. (HALL, 1997, p. 16).

Para o autor, as trocas culturais que acontecem por meio das tecnologias da informação criam a possibilidades de aprofundamento em diferentes culturas, inclusive com o aparecimento de novas culturas que se entrelaçam "entre o velho e o novo" (HALL, 1997, p. 19). Ao perceber o desenvolvimento cultural, dessa forma, o autor se contrapõe àqueles que pensam que corremos o risco de, em pouco espaço de tempo, passarmos a ter uma única cultura, em termos globais, devido à velocidade do tempo e da diminuição dos espaços referentes aos recursos tecnológicos.

Quando fala sobre a centralidade epistemológica, o autor apresenta o que chamou de virada cultural e diz que sua origem está na mudança de ações no modo de compreender a linguagem. Para isso, parte da concepção de que a linguagem, de forma geral, constitui a 
realidade, podendo ser utilizada para a compreensão da vida social. Dessa forma, a virada cultural explicada por Hall (1997) pontua que a cultura se mantém simultaneamente com os aspectos sociais, políticos e econômicos. Explica que a cultura não está nem acima nem abaixo da política e da economia, e sim que a cultura se envolve em todos os aspectos desses campos.

Outro ponto abordado por Hall (1997) se refere à regulação cultural. O autor discorre com propriedade sobre a relação entre cultura e poder, para servir de ligação ao exame do modo como a esfera da cultura é governada. A partir dessa relação, manifestam-se questionamentos sobre a cultura e a mudança cultural. Diante dessa discussão, aborda duas tendências na direção da política cultural, quais sejam: a regulação e a desregulação.

Em relação à questão do governo da cultura, Hall (1997) destaca a relevância de saber de que modo ocorre a regulação, confirmando que a cultura nos governa. Isto é, regula nossas ações e práticas sociais. Portanto, a maneira como nos comportamos no campo das instituições e na sociedade significa que somos influenciados pela cultura. Para o autor, há três tipos de regulação por meio da cultura: a) normativa; b) por meio de sistemas classificatórios e c) pela constituição de novos sujeitos. A normativa torna nossas práticas humanas previsíveis, marcadas por regularidade e propósitos bem definidos, ou seja, evidenciam que "as nossas ações são guiadas por normas, no sentido de que ao fazermos alguma coisa temos de ser capazes de prever seus fins ou propósitos, de modo a alcançá-los" (HALL, 1997, p. 41). A regulação por meio dos sistemas classificatórios estabelece os limites de nossas ações sociais, ou seja, "classificam nossas condutas de comportamento definindo os limites entre as semelhanças e diferenças, entre padrões os quais são aceitáveis ou não" (HALL, 1997, p. 42). Por fim, a regulação por meio da produção ou constituição de novas subjetividades estipula o tipo sujeito que nós somos ou podemos nos tornar, isto é, a implementação de um novo gerenciamento ideológico "tentará regular a cultura da organização social de uma comunidade e influir na conduta dos sujeitos trabalhando diretamente sobre a subjetividade dos mesmos - produzindo ou construindo novos tipos de sujeitos" (HALL, 1997, p. 43).

Tomando como base as reflexões de Stuart Hall (1997), é possível observar que a cultura está inserida em todos os campos da sociedade, influenciando o modo de vida das pessoas, especialmente por meio do acesso às informações pelos recursos tecnológicos atuais. Nesse contexto, acredita-se que as narrativas produzidas em Libras, em material audiovisual, se apresentam como uma nova manifestação cultural que põe o corpo em evidência, de modo que este se torne um texto poético cuja estética se constitui na inventividade da expressividade. 
Assim, nessa direção, depreende-se que essas narrativas promovem mais visibilidade à literatura surda e, consequentemente, à cultura surda.

\section{Procedimentos teórico-metodológicos}

Tendo em vista os objetivos deste trabalho, isto é, analisar o vídeo "As aventuras de Pinóquio", da editora Arara Azul, traduzido para por Nelson Pimenta de Castro, esta pesquisa se caracteriza como documental, visando à análise da expressividade do corpo na produção de sentido nas narrativas em Libras.

Considerando a natureza da fonte de pesquisa, recorreremos aos estudos de Napolitano (2005), que pondera sobre a necessidade de perceber as fontes audiovisuais "em suas estruturas internas de linguagem e seus dispositivos de representação da realidade, a partir de seus códigos internos para sua relação com o contexto sociocultural em que foram produzidas e que circulam" (NAPOLITANO, 2005, p. 236).

Partindo dessas informações, torna-se viável destacar que a leitura e a pré-análise da obra

“As aventuras de Pinóquio", em formato audiovisual, se constituirão como passo inicial desta pesquisa, além de serem a fonte primária dos dados para estudo. Em seguida, objetiva-se realizar uma nova leitura para a escolha das unidades de análise e das categorias que permitirão a classificação dos dados. Com isso, serão sistematizadas as informações com vistas à descrição e interpretação desses dados. Feitas as análises, será elaborada, finalmente, a apresentação dos resultados e das conclusões desta pesquisa.

\section{Sobre o vídeo}

“As Aventuras de Pinóquio”, obra publicada em 20 de março de 2014, por Nelson Pimenta, professor surdo do Instituto Nacional de Educação de Surdos (INES), dirigida e adaptada por Luiz Carlos Freitas e pela Editora Arara Azul, foi produzida em versão bilíngue, língua de sinais e português escrito. Na descrição e análise do vídeo, serão considerados aspectos tais quais a encenação, a performance, as expressões não manuais, as expressões faciais do tradutor, os elementos verbais, os elementos imagéticos, os sons, os planos de fundo, a sequência narrativa, as técnicas de filmagem, os cenários presentes nos vídeos e a narração propriamente dita. Busca-se, assim, por meio de todas essas categorias, consideradas imprescindíveis a este trabalho, apresentar quais técnicas foram ou não eleitas para a composição da obra. 
Dessa forma, objetiva-se compreender como tais recursos influenciam na produção de sentido nos textos produzidos em Libras. Isto é, evidenciar como ocorre, nessas obras literárias, a expressividade do corpo em consonância ao texto original, visando identificar que sentidos essa tradução de literatura em língua de sinais, através de elementos audiovisuais, podem ser provocados no receptor.

\section{Materialidade do vídeo}

Figura 1 - capa do DVD

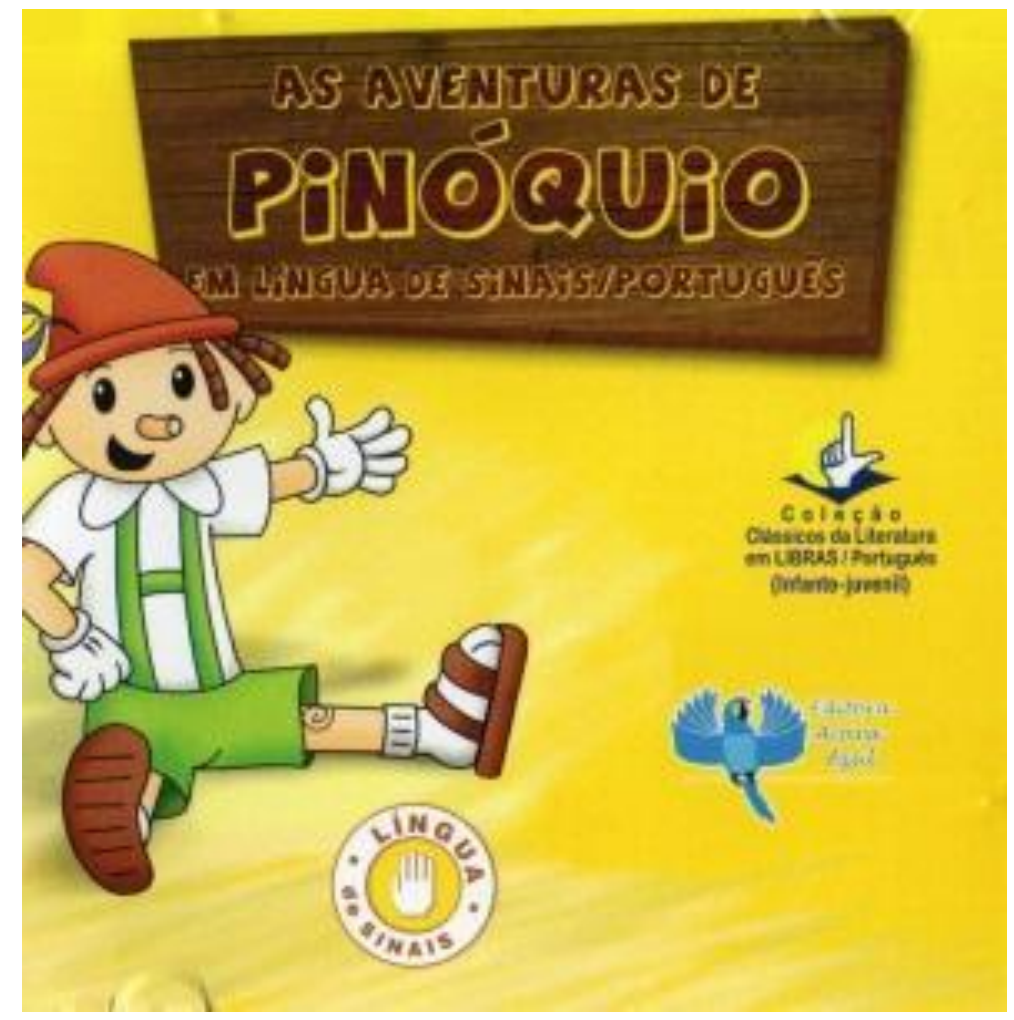

Fonte: As Aventuras... (2014, DVD)

Em um primeiro momento, cabe evidenciar que a obra em análise se subdivide em 08 (oito) capítulos, com 20 cenas, de modo que as cenas narradas por Nelson Pimenta podem ser claramente destacadas umas das outras, porém sempre interligadas. Para isso, no entanto, não são utilizados recursos visuais em relação à constituição do plano de fundo, que se resume a uma tela na cor azul. Além disso, a edição do vídeo conta com uma divisão do espaço disponível da tela utilizando gravação close $u p^{3}$ para algumas cenas, a fim de fazer marcação com mais ênfase no tradutor para essa narrativa em língua de sinais. 
Dessa divisão, surgem, na lateral direita, algumas ilustrações que servem de âncora ${ }^{4}$ (figura 2). A partir desse apoio, possibilita-se que os sujeitos com pouca fluência em Libras ou com dificuldade de compreensão no que diz respeito à narrativa consigam correlacionar a sinalização com a ilustração e com o texto em português. Assim, as imagens que constituem a obra facilitam o entendimento do texto sinalizado, além dos movimentos e sentimentos refletidos pelas ilustrações.

Figura 2 - Página virtual com texto bilíngue (Libras/Português)

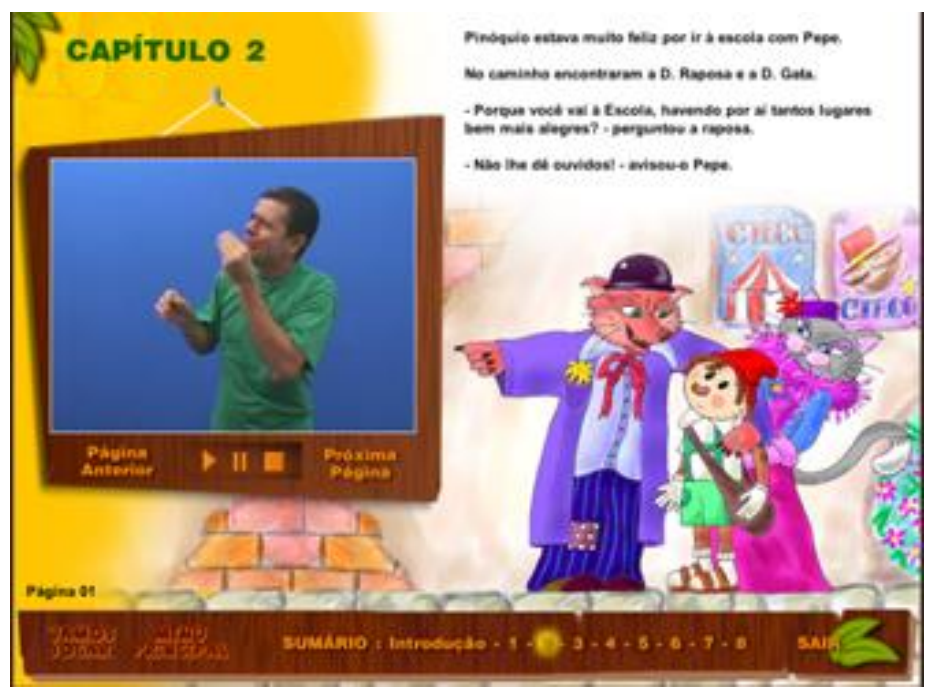

Fonte: As Aventuras... (2014, DVD)

Quanto aos recursos de áudio, observou-se também que o vídeo em questão não possui nenhuma espécie de efeitos sonoros. Em consonância a isso, evidencia-se a utilização de um único figurino por parte do tradutor, o qual permanece durante todo o vídeo com uma camisa da mesma cor (verde). Entende-se, então, que tal escolha tenha objetivado não desviar o foco do leitor para as vestes do tradutor em si, mas ressaltar a narrativa por ele apresentada.

Em relação ao desempenho do tradutor, é possível destacar que sua atuação conta com propriedade de classificadores 5 como o de "instrumento" e o "descritivo" utilizados para a construção de cenário e ações dos personagens. Verifica-se uma riqueza no uso dos classificadores, tornando mais claro e compreensível os sentidos que se pretende enunciar. Desse modo, o tradutor viabiliza, no que tange a vivacidade da obra, que o leitor tenha acesso mais direto aos dramas dos personagens apresentados, de modo que vivenciem intensamente a narrativa sob análise. 
Conforme já apresentado, no vídeo produzido pela Editora Arara Azul, as falas dos personagens são apresentadas sempre por meio do discurso direto, na primeira pessoa do singular. Desse modo, nos (8) oito capítulos, o tradutor se performa, incorporando o discurso para personificar cada personagem da narrativa, a saber: o narrador, Gepeto, Pinóquio, a fada, Pepe, a raposa, a gata, Stromboli e, por fim, a baleia. O discurso do narrador ( $3^{\text {a }}$ pessoa) evidenciado por breves pausas nas falas dos personagens se apresenta no vídeo em momentos em que o tradutor olha diretamente para a câmera. Há, portanto, poucas interferências do narrador, pois a ênfase está no discurso direto que dá vida própria aos personagens que materializam discussões, pensamentos e atitudes. Desse modo, ao encenar os discursos, o tradutor torna a narrativa mais dinâmica.

Para cada personagem, Nelson Pimenta utiliza um perfil que se adequa à característica de determinada figura dramática. Além disso, o tradutor emprega as expressões faciais e corporais, os classificadores e a forma de usá-los, a movimentação dos ombros, o modo de olhar e a personificação de cada de personagens da história, promove autenticidade e espontaneidade à narrativa. Com isso o tradutor mostra ao leitor as ações dos personagens em vez de simplesmente descrevê-las.

\section{Análise dos dados}

A sinalização utilizada para a narrativa se constitui por poucos sinais escolhidos pelo tradutor, o que não interfere na produção de sentido apresentada ao longo da trama, e a velocidade desses sinais é rápida. Entretanto, dependendo do personagem incorporado, a entonação pode ser mais lenta ou mais rápida. Um exemplo disso ocorre na cena de diálogo entre o grilo Pepe e Pinóquio, em que o grilo fala: "Não lhes dê ouvido, ignora, vamos para a escola!". Nesse caso, encontra-se um exemplo de sinalização mais rápida. Assim, para representar com mais perceptibilidade a análise, utilizou-se o recurso de decupagem $^{6}$ para a tradução do vídeo em língua de sinais, como segue na Figura 3. 
Figura 3 - Pepe

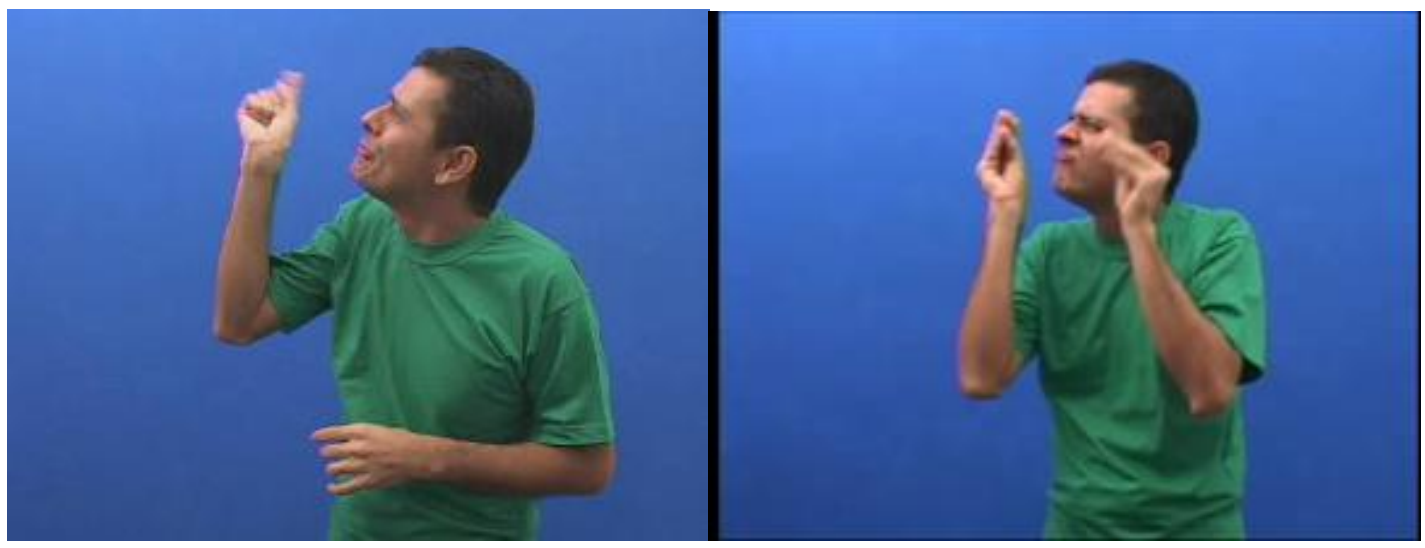

Fonte: As Aventuras... (2014, DVD)

Já na cena em que a fada encontra-se com Pinóquio e o manda ir para casa e para escola, a sinalização ocorre de maneira mais lenta, marcando, assim, a entonação da voz. A fada diz: "Volta pra casa, volta pra escola!", e Pinóquio, então, mente, dizendo que não tem casa. Nesse caso, o tradutor encenou o discurso por meio de uma sinalização mais lenta, porém ambas as 210 formas de sinalização não atrapalham o leitor a entender a cena, pois o tradutor tem uma memória corporal centrada. Ele, ao incorporar os personagens com movimentos, posturas e gestos, leva o leitor a comparar as figurações e a perceber a diferença entre elas, compreendendo os vários referentes da narrativa.

Figura 4 - Gepeto

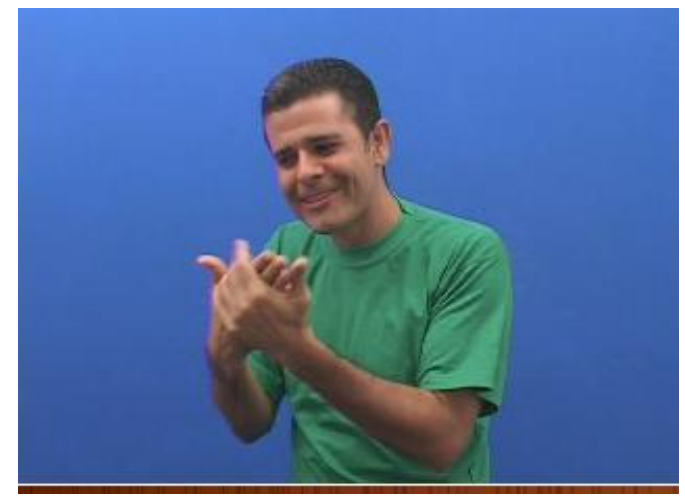

Fonte: As Aventuras... (2014, DVD)

Como exemplo, pode-se notar que, logo no início do vídeo, o tradutor incorpora o perfil do Gepeto (figura 4), um velhinho sereno, preocupado, emotivo. Para isso, Nelson Pimenta, em vez de utilizar o sinal de "idoso", utiliza um comportamento que remete a um senhor de idade, 
por meio de expressões faciais/ corporais que possibilitam tal compreensão, de acordo com a figura 3.

Além disso, percebe-se que, quando o tradutor representa o Pinóquio, personifica um menino alegre (sorriso no rosto), curioso (olhos bem abertos), andar desengonçado (braços, ombros e cabeça em movimentos desarticulados, assimétricos), querendo conhecer a vida. Como exemplo, pode-se verificar tal expressão na figura 5.

Figura 5 - Pinóquio

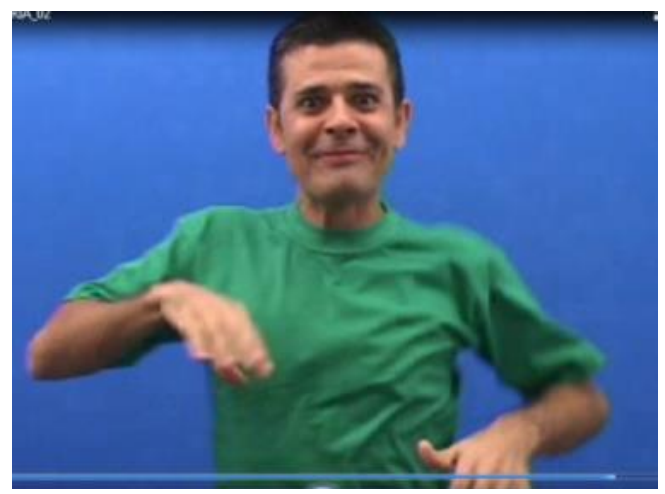

Fonte: As Aventuras... (2014, DVD)

Nesse mesmo sentido, ao incorporar a Fada, realiza movimentos mais lentos, suaves, expressão facial que denota bondade, dando a ver uma personagem amável, disposta a ajudar e, na maioria das aparições, parece estar segurando uma varinha mágica na mão direita como podemos ver na figura 6 .

Figura 6 - Fada

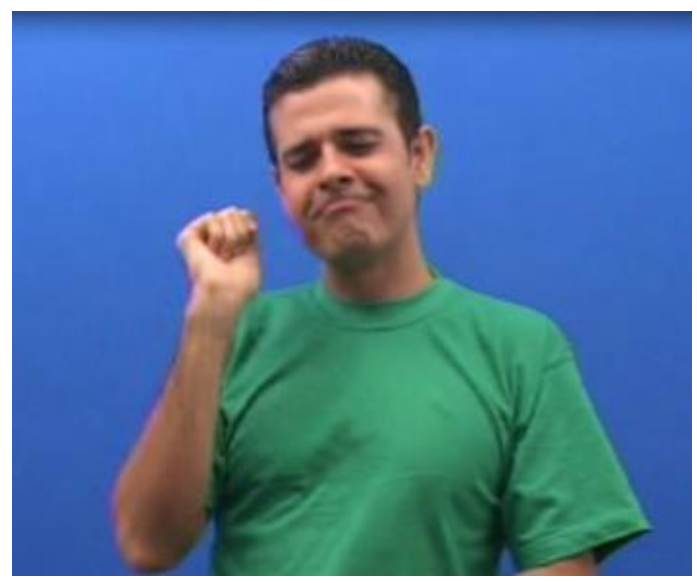

Fonte: As Aventuras... (2014, DVD) 
Percebe-se que, ao incorporar o grilo Pepe, figuras 7 e 8, o intérprete se apresenta com expressões corporais e faciais que denotam medo, tensão. Os ombros levemente elevados, o tronco meio encurvado e o olhar direcionado para cima caracterizam um personagem pequeno em relação aos outros.

Figura 7 - Pepe

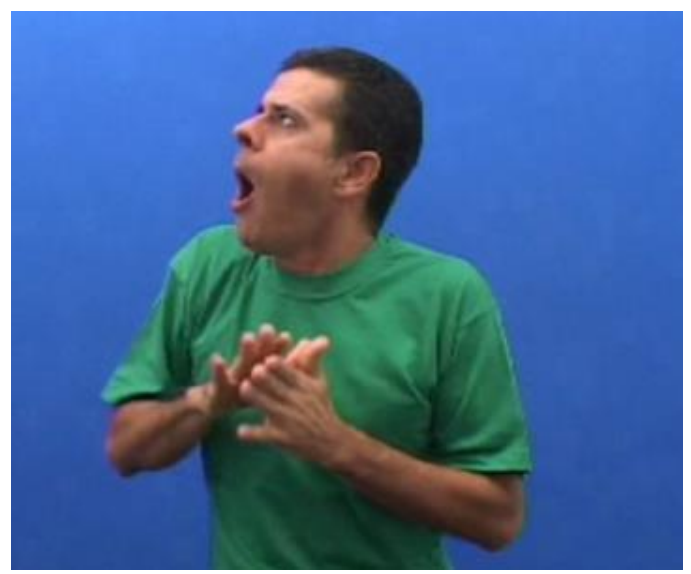

Fonte: As Aventuras... (2014, DVD)
Figura 8 - Pepe

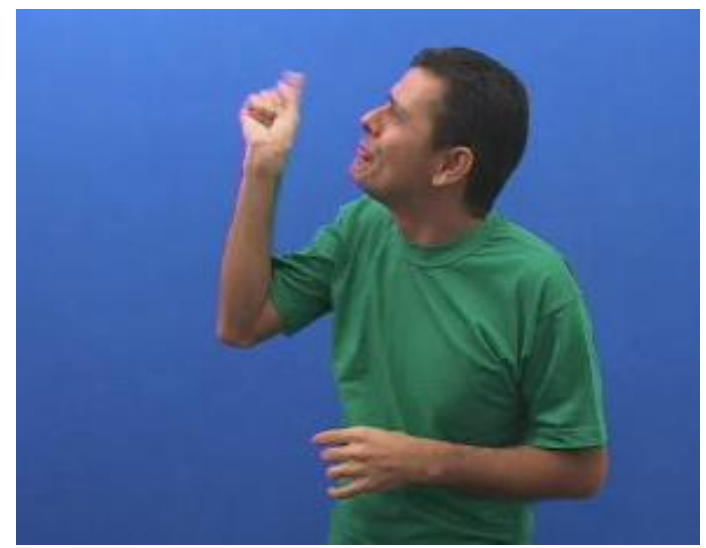

Fonte: As Aventuras... (2014, DVD)

Quando personifica o senhor Stromboli, incorpora características próprias de um sujeito argucioso, esperto, cujo interesse é somente lucro financeiro, o que se torna perceptível pela maneira como direciona o olhar, conforme mostram as figuras 9 e 10.

Figura 9 - Stromboli

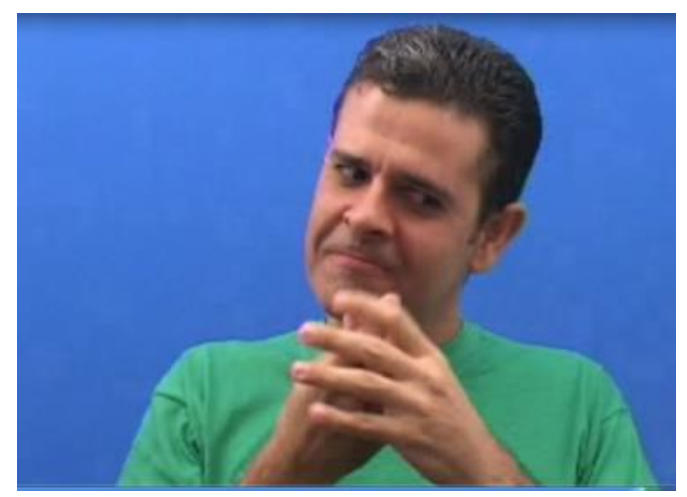

Fonte: As aventuras... (2014, DVD)
Figura 10 - Stromboli

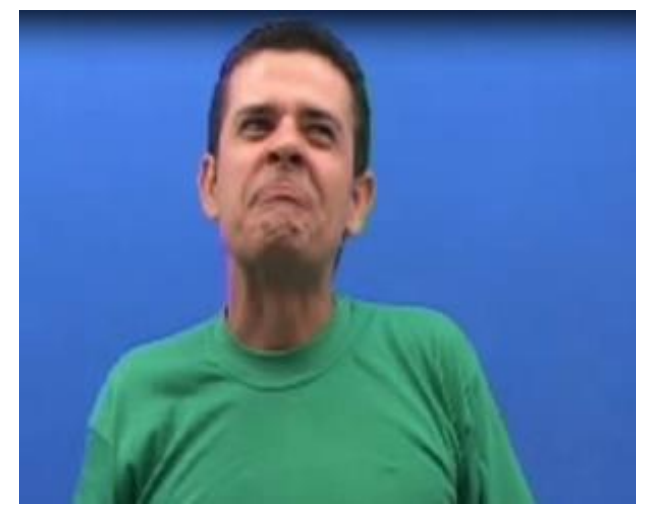

Fonte: As Aventuras... (2014, DVD)

À luz de Chartier (1990), entendemos que esses modos de narrar não são simplesmente criações espontâneas, inventadas de Nelson Pimenta. Antes, são práticas comunicativas próprias dos surdos por meio das relações sociais materializadas nas rodas de conversas, na forma de encenar e relatar os diálogos cotidianos. 
Assim, essa produção cultural evidencia que a representação das interações entre os surdos envolve a leitura não só do discurso no nível linguístico, mas principalmente, do corpo como local de discurso. Nessa perspectiva, o corpo produz significados ao estabelecer a conexão entre os mundos: interior e exterior. Cada performance guarda memórias de identidades, de modos de agir, de ser e estar no mundo.

Por outro lado, o uso do corpo como local de discurso tem uma dimensão cultural, na medida em que revela um modo de agir, interpretar e se relacionar com o mundo a partir da experiência visual. Assim, entendemos que o uso da gestualidade do corpo para transmitir ideias, comportamentos e emoção por Nelson Pimenta é uma ação social [...] significativa,

[...] tanto para aqueles que a praticam quanto para os que a observam: não em si mesma mas em razão dos muitos e variados sistemas de significado que os seres humanos utilizam para definir o que significam as coisas e para codificar, organizar e regular sua conduta uns em relação aos outros. Estes sistemas ou códigos de significado dão sentido às nossas ações (HALL, 2012, p. 16).

\section{Considerações finais}

Nesta pesquisa, objetivou-se analisar a expressividade do corpo na produção de sentido, no vídeo traduzido por Nelson Pimenta e produzido pela Editora Arara Azul, que trata sobre “As Aventuras de Pinóquio" em Libras. Com isso, através dos apontamentos destacados acima, viabiliza-se a compreensão de que o tradutor do vídeo utiliza recursos os quais fazem com que o leitor possa identificar as características de cada personagem, atribuindo-lhes sentido. Assim, entende-se que, para que o tradutor pudesse produzir esses sentidos, ele lançou mão de uma desenvoltura em relação ao uso dos classificadores, das expressões faciais/corporais, dos movimentos e dos elementos imagéticos, todos em consonância uns aos outros para que o leitor derive claramente a trama.

Além disso, corroborando o entendimento de Silva (2016), verificou-se que, nessa tradução, o tradutor atuou como "autor", pois em toda a narrativa houve um processo de "criação literária", a qual, como relata a autora, foi mediada por diferentes leituras, pelo saber do "texto escrito, visual, de sua memória sensorial, emocional, de um potencial leitor construído em sua mente, enfim, num processo ativo de produção de sentidos em que o tradutor também é autor" (SILVA, 2016, p. 10). Cabe evidenciar a partir dessas considerações que o tradutor domina a linguagem através do corpo, conferindo sentido à narrativa em língua de sinais e, dessa forma, promove a consolidação, o fortalecimento de uma nova forma de produzir literatura, por meio de cenas corporais, de texto literário que se manifesta no corpo do tradutor, 
produzindo sentido. Assim, enquanto o leitor ouvinte se emociona pelo que lê, o leitor surdo se emociona ao ler o texto literário performatizado nas práticas corporais expressivas do tradutor surdo. Por meio do trabalho realizado pelo tradutor, tornam-se visíveis as novas possibilidades para produção de literatura surda infantil.

Por fim, cabe ressaltar que foi feito neste trabalho um pequeno recorte de toda a complexidade existente na obra literária sob estudo. Assim, cabe apontar o fato de que nem todos os aspectos constitutivos da narrativa em Libras encontram-se enumerados e discutidos neste texto, tendo em vista a possibilidade de novas pesquisas relacionadas ao trabalho da Editora Arara Azul, bem como às traduções de Nelson Pimenta. Com isso, é possível que, a partir desta breve análise, surjam novos vieses de investigações linguísticas e culturais, que possam, por sua vez, promover, de maneira progressiva, representatividade aos grupos e culturas minoritárias.

\section{REFERÊNCIAS}

As Aventuras de Pinóquio em Línguas de Sinais/ Português. Traduzido por: Nelson 214 Pimenta de Castro. Coleção clássicos da Literatura em LIBRAS/Português (Infanto-Juvenil). Editora Arara Azul, 2014. DVD.

CHARTIER R. A história cultural: entre práticas e representações. Rio de Janeiro: Bertrand Brasil, 1990.

CLOSE UP. Disponível em: www.significados.com.br/close-up/. Acesso em: 07 jul. 2018.

DECUPAGEM. [2018]. Disponível em: https://www.infoescola.com/cinema/decupagem/. Acesso em: 07 jul. 2018.

FARIA-NASCIMENTO, S. P. Representações lexicais da língua de sinais brasileira: uma proposta lexicográfica. 2009. 290f. Tese (Doutorado em Linguística) Departamento de Linguística, Português e Línguas Clássicas, Universidade de Brasília, Brasília, 2009.

Disponível em: http://repositorio.unb.br/handle/10482/6547. Acesso em: jun. 2019.

HALL S. A centralidade da cultura: notas sobre as evoluções culturais do nosso tempo.

Educação \& Realidade, v.22, n.46, p.15-46, jul./dez. 1997. Disponível em: https://seer.ufrgs.br/educacaoerealidade/article/view/71361/40514. Acesso em: jun. 2019

KARNOPP, L. B. Produções Culturais em Língua Brasileira de Sinais (Libras). Letras de hoje, Rio Grande do Sul, v. 48, n. 3, p. 407-413, jul./set. 2013.

MORGADO, M. Literatura em Língua Gestual (Surd Universo - Portugal). In: KARNOPP, L. B.; KLEIN, M.; LUNARDI-LAZZARIN, M. Cultura Surda na Contemporaneidade: negociações, intercorrências e provocações. Canoas: Editora da ULBRA, 2011. p. 151-172. 
NAPOLITANO, M. Fontes Audiovisuais: A história depois do papel. p. 231-290. In: PINSKY, C. B (org.). Fontes Históricas. São Paulo: Contexto, 2005.

SILVA, A. B. A tradução de literatura infantil para língua de sinais: diálogos entre as ilustrações e o corpo sinalizante. In: V Congresso Nacional de Pesquisa em Tradução e Interpretação de Língua de Sinais Brasileira, Universidade Federal de Santa Catarina, Florianópolis, 2016. p. 1-11.

\footnotetext{
* Arlene Batista da Silva - Doutora em Letras (2015) pela Universidade Federal do Espirito Santo. Mestre em Linguística (2010) pela mesma instituição. Especialista em Língua Espanhola e Cultura Hispânica (2007) pelo Centro de Ensino Superior de Vitória. Graduada em Língua Portuguesa (2005) pela Universidade Federal do Espírito Santo. Professora da Universidade Federal do Espírito Santo. Vitória, Espírito Santo, Brasil.

Currículo acadêmico: http://lattes.cnpq.br/2371977118070548

ORCID: https://orcid.org/0000-0001-8153-5776

E-mail: arleneincrivel@gmail.com
}

** Marcilene da Penha Gonçalves Bravim - Graduada em Letras-Libras pela Universidade Federal do Espírito Santo. Vitória, Espírito Santo, Brasil.

Currículo acadêmico: http://lattes.cnpq.br/3215004430959519

ORCID: https://orcid.org/0000-0002-2348-4154

E-mail: marci_bravin@hotmail.com

${ }^{1}$ Este artigo é resultado do subprojeto de pesquisa de Iniciação Científica desenvolvido entre 2017 e 2018. Integrase ao projeto maior n. 6850/2016 "Tradução e Interpretação de Libras no contexto contemporâneo: desafios e perspectivas" e ao Grupo de Estudos e Pesquisas em Língua de Sinais Interpretação e Tradução (LISIT), desenvolvido pela professora Dra. Arlene Batista da Silva, do Departamento de Línguas e Letras (DLL/CCHN) e do Programa de Pós-Graduação em Letras da Universidade Federal do Espírito Santo (PPGL/Ufes).

${ }^{2}$ A expressão "língua gestual” é utilizada em Portugal para referir-se à língua de sinais.

${ }^{3}$ Expressão em inglês, bastante usada no ramo da fotografia e gravação de vídeos, que significa um plano onde a câmera está muito perto da pessoa ou objeto em questão, possibilitando uma visão próxima e detalhada.

${ }^{4}$ Informação importante, na qual a criança faz correlação com a sinalização.

${ }^{5}$ De acordo com Faria-Nascimento (2009), os classificadores (CLs) possuem função descritiva e classificadora na construção dos discursos. As configurações de mão (CMs) determinam os referentes principais a serem classificados. Entretanto, elas, por si só, não constituem o CLASSIFICADOR. O componente semântico completo só é interpretado a partir do momento em que a CM se articula como unidade lexical (UL). Elas são linguisticamente definidas e estão intimamente relacionadas à entidade que descrevem por meio de relações icônicas e/ ou metafóricas, cognitivamente determinadas pelos falantes da Língua de Sinais Brasileira (LSB) (FARIA-NASCIMENTO, 2009, p.117).

A modalidade visuo-espacial da LSB favorece a incorporação de várias funções ao CLASSIFICADOR, pois os CLs, de acordo com a forma e a posição que assumem no discurso, preenchem estruturas sintáticas com associações que vão de SUJEITO-VERBO a SUJEITO-VERBO-OBJETO-INTRUMENTO-MODO-ASPECTOLOCATIVO. (FARIA-NASCIMENTO, 2009, p.118).

${ }^{6}$ Do francês découpage, derivado do verbo découper, recortar - é no audiovisual, no cinema e na comunicação, a divisão do planejamento de uma filmagem em planos e cortes. 